\title{
The construction of European identity in fourth grade history handbooks
}

\begin{abstract}
Atalia ONIT⿱宀士 ${ }^{\bullet}$
Abstract

The fourth grade represents the first year of study of the discipline History for students in pre-university education. Before being a matter of civics, the European identity is a historically grounded construct; therefore, we naturally wondered whether the issue that we have not only an ethnic or national identity, but also a European one is, even incipiently, raised when teaching history. Our analysis started from the definition of the concept of European identity, to the general perception of Romanians regarding Europe according to Eurobarometer data, to reach the analysis of the school syllabus in the History discipline and then to the textbooks constructed starting from this syllabus. The conclusion we reached following our approach was that, as the school syllabus supports the formation of the national identity first and on a secondary place, the sketching of elements of European identity (through the elements related to the history of the national minorities in Romania, the location on the map of Europe of the events in the history of Romanians, discussing in different topics subjects such as the European Union or presenting some important personalities for the history of Europe), the three existing textbooks, available and at the decision of the teachers have an accordingly approach, that we consider to be correct. The European identity cannot be built before the national identity, historically speaking, and for the age category to which we refer (9-10 years), in the condition of one course hour per week, the simultaneous construction of the two types of identity (in other words teaching the history of Romanians and universal history at the same time) is difficult to achieve. Therefore, we believe that the choice for national history and identity before the European one is properly substantiated. The national and European identities cannot be constructed from the simple enumeration of historical names or data. The well-built explanation, accompanied by carefully chosen examples is essential in teaching history to this age category and, of course, in the solid construction of one's own identity (national and European).
\end{abstract}

Keywords: Europe, European identity, history, handbook, syllabus

\section{Introduction}

The concept of European identity has been most often correlated with the existence and functioning of the European Union, in the common language and the collective

- Lecturer, West University of Timișoara, Faculty of Sociology and Psychology, Sociology Department, atalia.onitiu@e-uvt.ro. 
perception being assimilated to a form of "supranational nationalism" (Checkel, Katzenstein, 2009, p.14), as John Meyer (2003, p.3) also stated

"the exact definition of Europe and its people is uncertain, variable, and for most participants unknown."

Since the first decades of existence of the European Union, its members have raised the question of building a common identity. Thus, in 1973, the year of Denmark's, Ireland's and the United Kingdom's accession on December 14, the foreign ministers of the nine Member States issued the Document on the European Identity (Available online at https://www.cvce.eu/content/publication/1999/1/1/02798dc9-9c69-4b7d-b2c9-

f03a8db7da32/publishable_en.pdf, last accessed on 4.10.2019). European identity is seen as a dynamic concept, in interdependence with the dynamics of the European Union. The document states that the following aspects must be taken into account when defining the European identity:

"reviewing the common heritage, interests and special obligations of the Nine, as well as the degree of unity so far achieved within the Community; assessing the extent to which the Nine are already acting together in relation to the rest of the world and the responsibilities which result from this; taking into consideration the dynamic nature of European unification".

In the same document it is stated that the elements underlying the European identity are: common values and attitudes, shared by all inhabitants of the Member States, preservation of national cultures in their diversity, defense of the principles of democracy, respect for human rights and laws, common market, institutions, policies and cooperation mechanisms. The European identity is understood in the document as an original and dynamic concept, which takes into account the diversity of cultures, the existence of common interests, values and principles.

Although with a long existence, both the European Union and the European identity, V. Sotirović (2014, pp. 100-101) argues in a recent study that the European Union is still a "multiethnic experiment" (Sotirović, 2014, p.102) and that one cannot speak of a European identity in the true meaning of the word. According to the author, the European identity is hardly under construction, suggesting the need to follow the French model of ethnic indifference (a model that implies the use in the public space of a unique official language, and according to which all citizens living within the borders of a state, regardless their ethnic origin, have an identity related to belonging to that state, which contributes to the development of the civic spirit, to the national and linguistic homogeneity and to the integration of minorities).

The idea that European identity is a construct under construction has been formulated previously, in a collective volume coordinated by Jeffrey T. Checkel and Peter J. Katzenstein (2009). In the opinion of the contributors to this volume the European identity does not exist, due to the fact that there is no single Europe, but a community of foreigners, therefore it is possible to speak only of multiple identities. European identity must be seen as both a social process and a political project (of the elites). As a project, 
the basis of the construction of the European identity is a series of mechanisms, the most important being, in the opinion of the authors, fear (Checkel \& Katzenstein, 2009).

European identity can be understood and interpreted in various forms, either as a cultural identity (based on common history), as a civic identity (related to the quality of European) or as a political, supranational identity (Tsumarova, 2012, p.139), forms of identity that coexist and are dynamic, all the more so as Europe is a dynamic space. Identity is a construct that is (re) defined continuously (Chaniotis, 2009, 48-49).

Comparing the European Union with the two models of antiquity, the Hellenistic world and the Roman Empire, A. Chaniotis concludes that the European Union lacks many elements necessary to speak of a collective identity: common citizenship, history and culture, unitary foreign policy, common language, religion, mythology, system of beliefs and values, myths and symbols. Homogeneity is lacking, given that Europe's defining element is diversity (Chaniotis, 2009, 49-51; Kreck, 2015, 157-158). Some authors believe that, despite its existence, materialized through different identities, regional or national, through territorial borders, but also cultural, social, political, ethnic, they do not exclude the possibility of a collective identity (Kreck, 2015, p.157). In the opinion previously expressed by G. Delanty, the European identity is not in opposition to the national identity, the two forms of identity coexist, the European identity being a form of collective, cosmopolitan identity, which must face the permanent dynamism of the contemporary world, and must form as a unitary construct, beyond the characteristic diversity of the European space (Delanty, 2003, p.76-86).

That national and European identity are not two opposing constructs is a fact reaffirmed by other authors, who consider that it is not the nation, but nationalism that opposes the construction of a European identity, and that to resist it, it is necessary to emphasize its cultural component, in order to develop the emotional attachment of individuals to Europe (Cinpoieș, 2008, 11-12).

\section{Romanians and the European identity}

In her work on European identity, Grete Tartler refers to an IRSOP study from 2005 (unfortunately the web page to which the author refers is no longer active), according to which European values such as "pluralism, minority rights, equality between men and women, freedom, democracy, tolerance, non-discrimination, human rights, equality, respect for the law, support for less developed regions, justice, human dignity" are not always respected in Romania (Tartler, 2006, p.173). In the opinion of Romanians, the political values would have ceased, not the economic, social or cultural ones, the Romanians being, unlike Europeans, inclined towards aggression, authoritarianism, dishonesty, disorganization, superficiality (Tartler, 2006, p.174).

Analyzing Eurobarometer data (available online at https://ec.europa.eu/commfrontoffice/publicopinion/index.cfm/Chart/index, last accessed on 7.10.2019), the question "How attached do you feel to Europe?", we can see 
the existence of significant statistical differences between the frequencies recorded in the years before Romania's accession to the EU and those after. Thus, in 2004, 44\% of Romanians declared that they are very attached to Europe, and 41\% quite attached, so practically an overwhelming majority, a situation that we find again in the following year ( $47 \%$ very attached and 38\% fairly attached). In 2014 and 2015 , on the other hand, only $18 \%$, respectively $22 \%$ feel much attached, $44 \%$ / $42 \%$ fairly attached, and the number of not very attached increases, to $26 \%$, respectively $21 \%$. However, despite these increases, we have over $60 \%$ of respondents who have declared themselves attached to Europe.

To the question "Do you ever think of yourself as not only (nationality), but also European? Does this happen often, sometimes or never?", Romanians offered in the years before joining comparable answers (15\% / 11\% often, 44\% / 46\% sometimes and 32\% / 38\% never), while to the question "Does the European Union give you personally the feeling of ...? (MULTIPLE ANSWERS POSSIBLE)", 67\% of Romanians answered hope and $45 \%$ confidence (in 2005).

According to the 2019 Eurobarometer, $60 \%$ of Romanians have a positive image of the European Union and 52\% have confidence in the European Union (data available online at https://ec.europa.eu/commfrontoffice/publicopinion/index.cfm/survey / getsurveydetail / instruments / standard / surveyky / 2253, last accessed on 7.10.2019), data comparable to the previous year (available online at https://ec.europa.eu/commfrontoffice/publicopinion/index.cfm/ Survey / getSurveyDetail / instruments / standard / yearFrom / 1974 / yearTo / 2018 / surveyKy / 2215, last accessed on 7.10.2019), when 59\% of Romanians declared themselves attached and very attached to the values of the European Union.

In terms of citizenship, $68 \%$ of Romanians identify themselves as European citizens; when it comes to nationality, $50 \%$ of Romanians declare themselves Romanians and Europeans. $20 \%$ of Romanians said that the main element of connection between the members of the European community is culture. Among the most important European values we mention human rights (36\%), peace (29\%) and democracy (25\%).

Therefore, it can be seen from the analysis of the statistical data, that it is possible to speak of a European identity among Romanians, that it is perceived above all as a civic identity, and that the national and European identity coexist in the Romanians' consciousness.

\section{European identity in the 4th grade history syllabus}

History as a subject matter is introduced in the school syllabus from the primary cycle starting with the fourth grade, in the curricular area Human and society [Man and Society / People and Society / Humans and Society], having an hour per week (according to Annex no. 2 to the Order of the Minister of National Education no. 5003 / 02.12.2014). 
There are four general competences formed through this discipline, and in the context of our analysis we will stop at the fourth one, namely "forming a positive image of oneself and others", in other words of national identity in a narrow sense, and regional and European in a general sense. As specific competences, the school syllabus mentions the specific competence "4.2. Recognizing the similarities and differences between oneself and the other, between individuals and groups", again with the undeclared purpose of shaping a national identity of students.

As can be seen in the Introductory Note, in the Learning Contents section, the building of national identity is stimulated, by reference to universal history and especially to the history of other European peoples (an example in this sense being the history of the national minorities that are found in the Romanian territory):

„Most of the themes propose contents that concern national and European history. When applying the syllabus to the classroom, the teacher will be able to negotiate with the students the options for topics of European and national history. This way of applying the program responds to a principle of curricular design that aims to capitalize on the context of the school, according to the interests of the students, the didactic resources, support elements that the school can offer and even the option for a more traditional or more innovative didactic approach. In this context, we recommend that teachers approach from a European perspective at least one of the sub-topics of each field."

There are some observations deriving from this paragraph: the autonomy of the teacher regarding the application of the school syllabus; focusing the activity on the student, according to his needs and interests, including the active involvement of the students in making decisions on the topic to be addressed at the classes.

The learning process is based on three main areas, namely:

" The past and the present around us (Introductory concepts: past-present (millennium, century, decade, historical era), historical space, historical sources; Family: family past, family holidays, free time, daily activities; Local and national community: territory, housing and daily life, traditions, holidays, religion, monuments of heroes; Minority communities on today's territory of Romania; Childhood of today in the local community; Peoples of yesterday and today: map location, occupations, traditions, customs, holidays; knowledge of the world through travelers.

Ages, events and personalities (Antiquity (Legends and writings of the ancients about Dacians and Romans); The Middle Ages (Legendary figures of voivodes, rulers and local rulers in literary and historical works; Transylvania - multiethnic space. Village and city in medieval Transylvania; Historians and chroniclers about minorities' personalities); The Modern Age (Al.I. Cuza and the Union; Carol I and the Independence, Carol Davila; Heroes of the First World War; Ferdinand and the Great Union; Romania at the turn of the millennium).

Culture and heritage (Historical places in the community: monasteries, streets and historic houses in the community, monuments of heroes, representative monuments of 
ethnic communities in Romania; Places of historical importance for Romania: Dacian settlements and constructions, Greek and Roman (Greek cities on the Black Sea shore); castles and fortresses of historical events; religious buildings and their founders; Monuments and places included in the UNESCO heritage".

Some basic observations can be made from the simple reading of these contents: the history taught to the students of the fourth class is one that emphasizes the local and national, integrated into a universal context; learning the history of the local and national community also forms an identity feeling, and analyzing the communities of minorities or the history of various peoples, by relating to others, the regional and European identity is shaped.

\section{European identity in the $4^{\text {th }}$ grade history textbooks}

Three are the textbooks available to teachers for teaching history, namely (We have consulted the digital handbooks available online at https://www.manuale.edu.ro/.): Doina Burtea, Alina Perțea (2016), Istorie, Bucharest: Aramis Publishing House; Cleopatra Mihăilescu, Tudora Pițilă (2016), Istorie, Bucharest: Aramis Publishing House; Zoe Petre (Eds.), Bogdan Teodorescu, Corina Andrei (2016), Istorie, Bucharest: Corint Publishing House. Each of the three textbooks is structured in two parts, for the two semesters of the school year.

We will analyze each of these textbooks, in terms of content, to see in a concrete way how the competences provided in the school syllabus are formed and, in particular, how the European identity of the students is constructed through the history textbooks.

\section{Doina Burtea, Alina Perțea (2016), Istorie, Bucharest: Aramis Publishing House, Part I}

The images selected for the cover of the manual suggest not only the idea of chronology and historical time (prehistory, antiquity, middle ages, contemporaneity), but also presents "us" (through the image of the Citadel of Neamț with the Romanian flag hoisted) and "others" (through the Roman temple and the rocket launched in space), an expression of the intention of identitary construction.

The second page contains very important information for our approach, but especially for the perception of the students, namely the insertion of the European telephone line for child support, an indirect form of belonging to the European space.

The national anthem and the specific symbols (flag and coat of arms) on page 5 of the textbook do not require any further comment, the purpose of which is more than obvious.

From the first lesson ("What is history?") it is possible to observe the accessible language, corresponding to the age, the use of drawings, suggestive images, a cartoonish style of transmitting knowledge, focusing on chronology. Although in line with the provisions of the syllabus regarding the integration of national history into the European and universal context, we believe that the inclusion of examples such as the 100 Years War between England and France (p. 6) in an introductory lesson is a little uninspired 
and unfounded, as at this stage in their education the students do not yet possess the background information necessary for understanding it.

Learning unit 3 - "The local and national community" transmits, as stated on page 31, knowledge to the students about the local community, the national community, about the historical-geographical areas of Romania, but also about UNICEF. The language is preserved in the same childish note, of a story, but again lacking in consistency with regard to the concrete examples offered, as is the case with the presentation of UNICEF and especially of the UN. However, while UNICEF receives a definition in the Vocabulary section, the UN is only mentioned in passing (p. 34). The same situation can be found in the case of objectives such as the Adamclissi monument, historical events (wars with the Turks) or Romanian rulers (Vlad Țepeș, Mircea cel Bătrân), who are merely mentioned (p. 38).

In order to convey to the students' knowledge about the national community, the authors first choose to place our country on the map of Europe (p. 40), followed by the enumeration of the ethnic minorities in Romania and the geographical regions in which they can be encountered (p. 41). In the section "How do you interpret?" on the next page (42), there are two short paragraphs about the Roma. Also, in the section "How do you interpret?" on page 45 , it is stressed that minorities have their own language and customs, the students being encouraged to find out on their own about the minorities in our country.

Learning unit number 4, "People of yesterday and today (I). Antiquity", briefly gives information about the Dacians and the Romans, but also about the Gauls, Greeks and Slavs. The spatial location at the European level of these peoples occupies a significant place in the text economy, by the inclusion of maps. Unfortunately, not the same thing can be said about temporality: the three peoples are analyzed concomitantly, although chronologically speaking their presence and action is consecutive, not simultaneous.

\section{Doina Burtea, Alina Perțea (2016), Istorie, Bucharest: Aramis, Part II}

Learning unit 5 - "Peoples of yesterday and today (II). The Middle Ages" continues in the same way the presentation of the Romanian medieval states, emphasizing some aspects such as the way in which the medieval institutions were founded. Spatial location also occupies an important place, by including at the beginning of each theme a relevant map. The accessible and friendly language, the first-person narrative of the Romanian rulers, the rich illustration are likely to come to the aid of the students, for a better understanding of the historical events and facts. However, we notice that the inconsistency and insufficiency of historical information has a negative effect, it requires an additional effort, both from the teacher and the students, to detail and clarify the many missing elements, without which the correct and complete reconstruction of the historical past, of the relations between communities, understanding the causes of many conflicts that existed between the European peoples is not possible. 
Theme number 3 - "Middle Ages in the World - Turks, French, English, Hungarians, Russians" tells in three pages (14-16) aspects of military and political history, with emphasis on spatial location (via map), and on enumeration, without giving detail, of some leaders (with their reign) or events (with their period). Although welcomed as an intentionality, for the purpose of creating an image of "the others", different from "us", a necessary and useful step in the identity construction, this theme is not, from a historical perspective, sufficiently well and properly constructed, transmitting too little information about what the Middle Ages actually meant and about the specificity and history of the peoples announced in the title. Reading the title, the reader expects to find information about people, in terms of history, culture, customs, specificity. The textbook, however, approaches the subject from the point of view of the state formations, failing to outline a sufficiently conclusive image neither of the peoples, nor of the political-military history, nor of the historical period itself.

Theme number 4 - Legends and historical writings about the great rulers offer on two pages (17-18) examples of remarkable leaders from the Romanian and European Middle Ages. The authors choose the legend of Dragoș, the founder of the medieval state of Moldova and a poem about Stefan cel Mare, and for Europe they stop at Louis XIV (dedicating over half a page to his daily program) and Queen Elizabeth of England (the students learn that her reign was called the "Golden Age", but it is not explained why, instead it is emphasized that the queen had smallpox-like marks and that legislatively regulated the clothing of her subjects).

Learning unit 6 - "People of yesterday and today (III). The modern age" tells in 15 pages (from 25 to 40) the modern history of Romania, from the Revolution of 1821 and that of 1848 (mentioned by means of comic strips), to Alexandru Ioan Cuza and the Union of the Principalities, the War of Independence and Carol I, World War I and Ferdinand I, the Union of 1918. Three pages (38-40) are assigned to the other peoples of Europe ("Turks, Hungarians, Germans, Russians, Serbs and Bulgarians"). The economy of the page is dominated by maps, images and comics. The information itself is still incomplete and insufficient.

"Romania at the turn of the millennium. The Contemporary Age" is Learning Unit 7. The objectives it aims to achieve set out on page 47 draw our attention:

,$\sqrt{ }$ to analyze the economic situation of the Romanian people at different times;

$\sqrt{ }$ to identify the progress of the Romanian society in the Contemporary Age;

$\sqrt{ }$ to name the leaders of contemporary Romania;

$\sqrt{ }$ to identify the positive and negative parts of the various periods in the contemporary history of Romania."

Students are supposed to carry out economic analyses, although this is not the purpose of history as a discipline, and make valuable considerations, based on a learning unit covering only 10 pages (48-58). The contemporary history of Romania, including the Second World War, the monarchy, the communist period, the Revolution of 1989 unfold before the eyes of the students through maps, pictures and tapes, with 
brief and insufficient information, we would say, to outline a comprehensive picture of the contemporary period, much less allow students relevant and well-argued assessments.

\section{Conclusions}

Going through this first textbook we can draw some conclusions: it aims to present the history of Romanians from the beginning to the present, with reporting and framing, whenever possible, in European history; the language is accessible to students, with an emphasis on images; events and characters from the history of Romanians and from the history of Europe are presented in a comparative register, as well as a significant number of maps, which allow students to acquire knowledge about the historical space, but which, categorically, contribute to the construction of a national identity and, why not, a European one. Beyond these positive aspects as a whole, we cannot ignore the negative aspects, namely that the actual text and historical information are completely overshadowed by images, insufficient and inconsistent. The historical periods are presented in the form of brief information, inaccuracies and in some cases less relevant. For the age category in which this textbook is used, because we are talking about the first year of history study, we believe that not the quantity but the quality of the information should prevail, which will give the students a correct perspective and good understanding of the historical phenomena. The accessible form is not sufficient, and the content must be carefully selected and accessible. The form in which this textbook is presented, which in two parts of 66 pages (including numerous maps, images, recapitulative sequences and tests of knowledge assessment) covers the whole history of Romanians and sequences of universal history, is not a viable tool, nor enough for one hour per week. An enormous puzzle with many missing pieces cannot help the fourth-grader to understand the history of their people, much less the history of the neighbouring countries or of Europe, a continent which in this manual is made up of a number of people well located on the map, with some leaders or events mentioned in passing. Identity construction is intentional, but insufficiently sustained.

\section{Cleopatra Mihăilescu, Tudora Pițilă (2016), Istorie, Bucharest: Aramis Publishing House}

Analyzing from the perspective of identity construction the cover of this second manual, we find that the authors opted for symbolical images, meant to outline at least one national identity, not a European one: the statue of the goddess Minerva, of Emperor Trajan, an image of war, the coronation of the King Ferdinand, the Great National Assembly of Alba-Iulia, and in the background a clock and a cathedral, nowhere explained to the students, probably being left to the teacher's decision.

The child's European telephone line and the national anthem with the symbolic insignia (flag and coat of arms) are present, identical to those in the previous manual. 
We notice from the first learning unit that we have a slight paradigm shift in the content approach. Although the form is still accessible, the emphasis does not fall solely on the form, but also on the content. The images are no longer so cartoonish, but are taken from reality, even if they are still not explained. Roman inscriptions and coins are pasted to the same page as Greek vessels, without any explanatory legend (page 7).

Speaking of family (pages 10-13), the authors include the image of a birth certificate, suggestive we consider for what identity construction means. Unfortunately, we cannot help but notice that the examples could have been taken from history, not from literature, since it is, after all, a history textbook.

We cannot fail to notice the careful manner, and we do not refer to the form, in which the authors explain the concept of minority and the relationship between the Romanian majority and the national minorities in our country, a very important element for the identity construction.

However, the reference to the right of children to citizenship (p. 18) or to the General Assembly of the UNO (p. 20) without other explanations is not so appropriate.

Theme 6 of Unit 1, namely "Peoples of yesterday and today", particularly important not only for understanding national and European history, but also for developing identity, includes some aspects that we would like to emphasize: inclusion on the same map of the peoples of antiquity and those of the Middle Ages (Slavs alongside Gauls, Germans, Dacians and Turks), without other adjacent explanations, without clarification of concepts such as colonization or migration, without a minimum history of events, violates the chronological principle and negatively affects the image that the students form about the history of Europe; the history of the peoples we find as minorities in our country should precede the lesson about minority communities, respecting the logic of events.

Unit 2 - "Historical times, events, personalities, historical places" stops at a chronological approach, starting with Antiquity. Information is presented on the history of the Greeks ("the first civilization of Europe"), Dacians and Romanians, the formation of the Romanian people. The ideological content is rich, but the inclusion of terms without defining them (civilization, polytheism, Romanization, province) does not bring any benefit to the students.

A certain superficiality is also found in the presentation of the medieval era (pp. 4245). The authors insist on focusing on the formation of the Romanian medieval states, but they do not place these events in the wider historical context, they do not provide explanations; we need to think about the foreign political situation that forced the formation of the Romanian medieval states, and their importance is insufficiently explained (p 44):

„The establishment of the Romanian medieval states meant a period of progress for the Romanians and the preservation of the national entity", without taking into account the fact that at that time the question of a "national entity" was not yet raised. 
The textbook continues with the presentation of the Romanian princes (Mircea cel Bătrân, Vlad Țepeș, Mihai Viteazul), continuing, in the second part with Stefan cel Mare and Iancu de Hunedoara. We cannot fail to find the authors' option to group the rulers not according to the chronological principle, but according to the territorial one, the presentation of the reign of Iancu de Hunedoara making the transition to topic 3 of Learning unit 3, namely "Transylvania - multiethnic space. Village and city in the Middle Ages. About minorities' personalities" (pages 14-17). We observe from the beginning that, although the title is extremely generous, it is not clarified, and the students cannot understand, from the simple reading, the concept of "multiethnic". Unfortunately, the four pages do not insist on clarifying the situation in Transylvania, the information being insufficient, we believe, to substantiate the concept of multi-ethnicity. As for the personalities of minorities, the only one referred to in the passage is Gheorghe Doja.

The following themes (Cuza and the Unification of the Romanian Principalities, the Conquest of Independence during King Carol I, Heroes of the First World War, King Ferdinand and the Great Union) (p. 18-33) focus on national history and little on European history, contributing to the much to the construction of national identity, but the focus is radically changed by theme 8 "Romania at the turn of the millenium", in which students learn about the European Union, the UN, NATO, the Euro currency and the EU flag, the composition of the EU and its institutions. Some contents important for our investigation appear on page 37, namely a reading proposed to students in a speech by the President of the Pan-European Union, Richard Nikolaus von CoudenhoveKalergi, on the European consciousness and identity, but also the topic of reflection addressed to the students, with the question "Do you think you can be Romanian and European at the same time?".

\section{Conclusions}

This second book published by Aramis Publishing House offers to the readers a different approach to the first. If in the case of the previous one we found an emphasis placed on the form, to the detriment of the content and the explanation, this time we can speak of some balance between the two. The textbook focuses on the transmission of Romanians' history knowledge, placed in the broader context of European history, contributing in a consistent way to shaping a national identity among students. According to the provisions of the curriculum, there is a theme dedicated strictly to the history of Europe and the European Union, with elements meant to contribute to the formation of the European identity.

With the minus of rigor mentioned above, this textbook is a viable tool in teaching history to fourth graders, contributing to the construction of a national but also a European identity. 


\section{Zoe Petre (Eds.), Bogdan Teodorescu, Corina Andrei (2016), Istorie, Bucharest: Corint Publishing House}

The last manual we will refer to has as editor a significant personality of Romanians history, namely Ms. Zoe Petre. The editors opted for a simple cover, with a single image inserted - Trajan's Column (for the first part) and the first siege of Constantinople (for the second part) - in other words Antiquity and the Middle Ages, Romania and Europe. We find both the child's European telephone line, the national anthem and the symbols (coat of arms and flag).

It can be seen from the first lesson that, unlike the previous textbooks, here the written information, the explanation is the one that predominates in the economy of the text, written in the second person singular. The emphasis is more on the student, including the fact that the concepts taken from the school syllabus (learning unit, competences), which is difficult for a child to understand, were given up. This textbook seems addressed to children, and not to teachers, which we consider a positive trait. The first lessons about time and family includes general concepts, but we notice the emergence of examples, this time explained, taken from the history of Europe, whether they are in text or image form.

The lesson "Life in the local and national community" (p. 14-17) explains to the students the concept of community, whether local, national or minority, with carefully selected examples and information, designed to build national identity, but also to stimulate tolerance, understanding and acceptance of others.

In presenting the "Peoples of yesterday and today" (p. 20-29) the authors respect not only the chronological principle (first presenting the peoples of antiquity and later the medieval ones), but also of the equity one, allocating a consistent space to each presented population and providing information on their history. The authors focus on the explanation, with a story-telling tone, appropriate to the age, not on historical data and we find a special attention to details, no new concept being left unexplained. Finally, we find a fundamental lesson for the construction of identity, namely the one about the ethnogenesis of the Romanian people (p. 26).

"Getting to know the world through travelers" is another theme (pp. 30-33) where the universal is interwoven with the national, as if showing the students that they have reason to be proud that they are Romanians.

The construction of national identity continues on the pages that present, this time respecting the historical correctness of the chronological course, the rulers of the Romanian Countries from the medieval era (pp. 42-53).

Pages 54-61 are assigned to Transylvania, with its multiethnic specificity. Without abusing data, in an accessible way, respecting the principle of "sine ira et studio", the authors explain the situation of Romanians, but also of the other populations colonized in the territory of Transylvania in an equitable way, without making value judgments, on the contrary, offering striking examples of personalities of Hungarian or German origin, either cultural, political or military leaders, who have positively impacted the 
history of the Transylvanian Romanians. Beyond national identity, the authors support the positive thinking of the students and the correctness of reporting on otherness, elements that contribute to the formation of a healthy transnational or European identity.

The second part of the handbook continues in the same way the presentation of events and personalities that have marked the modern history of Romania, starting with Al. I. Cuza. Europe becomes more present with the establishment of the monarchy, as students can learn that King Carol I came from a family related to the great monarchies of Europe (p. 10). The authors opt for an approach centered on national history, the elements of international relations being rarely mentioned, addressing the great moments that marked the existence of the Romanian people (World War I, Great Union, World War II, the establishment of the communist regime and its fall).

Page 28 brings to the attention of the students "The beginning of a new era in Romania's history, accession to NATO and to the European Union". Unfortunately, however, the two are presented briefly, the simple mention of the number of Member States and the symbols (flag, anthem, currency) are not enough to speak of a European identity.

The last major theme of the textbook, "Culture and heritage", refers exclusively to the national heritage, contributing fully to the construction of the national identity of the students.

\section{Conclusions}

Unlike the previous textbooks, we could see in the pages of this textbook a special care for the accuracy of information, for documentation, attention to detail and to the chosen examples, the language accessible to students, focusing not on difficult-toremember historical data, but on events, told with a storytelling tone. The emphasis is on the national aspect, with little being said about the European and universal aspects. By including a lesson about the European Union, the textbook respects the provisions of the school curriculum, but it draws attention, and we believe that it is right, to the fact that before being Europeans we are Romanian, that without first knowing the history of our people we cannot know and understand European history. Given that it is the first year of studying history in pre-university education, we consider that this approach is correct and justified.

\section{Final conclusions}

The analysis of the three history textbooks available for teaching History in the fourth grade highlighted three distinct approaches to the same content. Some authors have opted for a form to the detriment of the fund; others have sought to strike a balance between the two, while the latter have emphasized the content, without 
neglecting the importance of the form in which the information was exposed. Definitely, being a category of students of young age (9-10 years), history must be made accessible. The emphasis on chronology and events should be pushed back to a secondary level of importance, the story and the causality, the understanding of the context having to prevail.

As we have seen from the school syllabus, one of the main objectives of teaching this discipline in the fourth class is to build the national identity and to establish some fundamental benchmarks for the construction of the European identity. More or less each of the three textbooks contributes to this objective. Before being European, as stated above, we are Romanians, the two forms of identity are not excluded, on the contrary - we are also Romanian and European, but in order to understand the general we must start from the particular, in this case the history of the Romanian people. Our identity is constructed only by reference to the otherness, present in the above textbooks through the ethnic minorities, the peoples with whom the Romanians have come in contact over time, the states with which they had peaceful relations or conflicts. The maps, present in all three textbooks, bring an important contribution to the placement not only of events, but also to our location in the wider European context. Students can thus find out, indirectly, that we are part of Europe and that all events that have affected our existence have been part of a wider European context. Therefore, we can speak unequivocally of a European identity construction in the history textbooks used in fourth grade.

In our opinion, teaching history should not be merely a matter of substance or merely a form, but a balance must be reached between the two; the chronological principle must be respected for the correct understanding of the causal relationships between historical facts; judgments on values do not belong here, the language must be appropriate to the age of the students and make the content comprehension accessible, not difficult; the textbook is primarily a tool for the student, and not the teacher.

\section{References}

Chaniotis, A. (2009). European Identity. Learning from the past? In Angelos Chaniotis, Annika Kuhn \& Christina Kuhn (Eds.), Applied Classics. Comparisons, Constructs, Controversies. Stuttgart: Steiner Verlag, 27-56.

Checkel, J.T., Katzenstein P.J. (2009). Conclusion - European identity in context. In J.T. Checkel, P.J. Katzenstein (Eds.) European Identity. Cambridge University Press, 213227.

Cinpoieș, R. (2008). From National Identity to European Identity. Journal of Identity and Migration Studies, 2, 1, 3-14.

Delanty, G. (2003). Is There a European Identity? Global Dialogue, 5, 3/4, 76-86.

Girault, R. (Eds.) (2004). Identitate și conștiință europeană în secolul al XX-lea. București: Curtea Veche. 
Kreck, V. (2015). European Identity Concepts and the European Idea, Journal of Intercultural Studies (Kobe University), 45, 117-144.

Meyer, J.W. (2000). The European Union and the Globalization of Culture. Paper presented at the Workshop on Institutional Approaches to the Study of the European Union, Oslo: Arena Centre for European Studies, University of Oslo (March).

Moes, J. (2008). European identity compared. A mixed methods approach. Prepared for the ECPR fourth Pan-European Conference on Eu-Politics, 25-27 September, RIGA, LATVIA

Petithomme, M. (2008). Is there a European Identity? National Attitudes and Social Identification toward the European Union. Journal of Identity and Migration Studies, 2 (1), 15-36.

Pinxten, Rik, Cornelis, Marijke, Rubinstein, R.A. (2007). European Identity: Diversity in Union. Intl Journal of Public Administration, 30, 687-698.

Rusu, H. (2008), Identity and axiological profile: value identifications for Romanian young people. In B. Voicu, Mălina Voicu (Eds.) The Values of Romanians: 1993-2006. A sociological perspective. Iași: Institutul European, 232-260.

Sotirovic, V.B. (2014). The European Union and The European Identity. In Contemporary Approaches to the Self and the Other. Vilnius, 99-119.

Tartler, Grete (2006). Identitate europeană. București: Cartea românească.

Tsumarova, Elena (2012). European Identity in Crisis. Some Perspectives for the European Identity Studies. In Elena Belokurova (Eds), European Politics and Society: Studies by Young Russian Scholars, Vol. 4. St. Petersburg: Svoe Publishing House, 139-150 